\section{The urban environment from the health perspective: the case of Belo Horizonte, Minas Gerais, Brazil}

\author{
O urbano sob o olhar da saúde: \\ o caso de Belo Horizonte, Minas Gerais, Brasil
}

\author{
1 Faculdade de Medicina \\ Universidade Federal \\ de Minas Gerais, \\ Belo Horizonte, Brasil. \\ 2 Observatório em Saúde \\ Urbana em Belo Horizonte, \\ Universidade Federal \\ de Minas Gerais, \\ Belo Horizonte, Brasil. \\ 3 Gerência de Epidemiologia \\ e Informação, Secretaria \\ Municipal de Saúde \\ de Belo Horizonte, \\ Belo Horizonte, Brasil. \\ Correspondence \\ W. T. Caiaffa \\ Departamento de Medicina \\ Preventiva e Social, \\ Faculdade de Medicina, \\ Universidade Federal \\ de Minas Gerais. \\ Av. Professor Alfredo Balena \\ 190, Belo Horizonte, $M G$ \\ 31130-100, Brasil. \\ wcaiaffa@medicina.ufmg.br
}

\begin{abstract}
This study aims to determine spatial patterns of mortality and morbidity for five health problems in an urban environment: homicides, adolescent pregnancy, asthma hospitalization, and two vector-borne diseases, dengue and visceral leishmaniasis. All events were obtained through the city health database and geoprocessed using residential addresses and 80 planning units consisting of census tracts. We used thematic maps, proportionate mortality/morbidity ratios by planning unit, and the overlapped rank of the 20th worse planning unit rates for each event. A spatial pattern of high rates of homicides, proportion of young mothers, and hospitalization due to asthma overlapped in socially and economically disadvantaged areas. For the two vector-borne diseases, high rates with great dispersion were found in underprivileged areas, in contrast with very low rates among higher income areas. The results indicated the coexistence of heavier disease burden for residents of urban areas where poverty and lack of effective public health policies may be modulating social health problems. For the two vector-borne diseases, an environmental intervention in one mosquito-borne disease might be playing a role in the other's incidence.
\end{abstract}

Cities; Spatial Analysis; Urban Health
Waleska Teixeira Caiaffa 1,2

Maria Cristina de Mattos Almeida 2,3

Claúdia Di Lorenzo Oliveira 1,2

Amélia Augusta de Lima Friche 2,3

Sônia Gesteira e Matos 2,3

Maria Angélica Salles Dias 2,3

Maria da Consolação Magalhães Cunha 2,3

Eduardo Pessanha 2,3

Fernando Augusto Proietti 1,2

\section{Introduction}

Research in the field of urban health has been the target of changes, incorporating individual and downstream determinants and compositional and contextual attributes 1 .

The traditional urban health model, centered on infectious diseases, has been replaced by a focus on acute and chronic diseases, highlighting asthma, depression, obesity, the emergence and reemergence of vector-borne diseases like dengue and leishmaniasis, and the persistence of other diseases such as tuberculosis and malaria and events such as violence, homicide, and teenage pregnancy 2 .

Added to the emphasis on the urban poor and rural-urban comparisons and vulnerable groups is the concept of urban-rural interactions in cities with intra-urban differences as well as differences between and within households. The traditional concepts of the urban poor functioning as the reservoir for infections (and the target of everything bad) are expanded by the set of concepts including inequality, social capital, disease burden, and sustainability. Emerging interventions include healthy cities projects, multi-sector strategies, and reinforcement for the urban health team, accompanying decentralization, health sector reform, and governance 3 . 


\section{Why the urban space in Belo Horizonte?}

Belo Horizonte was founded in 1897 with the aim of becoming a physically organized, socially hygienic, and disease-free city, "free of disruptions and revolutions". Planned to contain three areas (downtown, suburban, and rural), it underwent a slow settlement process in three stages 4,5 .

The first stage was characterized by a process of organizing population groups in the urban space; government employees were allocated to live in the Funcionários (literally "Civil Servants") neighborhood and central areas. The peripheral areas, separated from the more central urban area by a major avenue, had more flexible settlement patterns. The rural area, initially known as the "Green Belt", currently an industrial area, underwent more rapid growth than the city center, contrary to the original planning and giving rise to the suburban areas. The downtown or city center area remained relatively unoccupied due to the prohibitive real estate rates. Today this area is characterized by vertical expansion, a reduction in unoccupied areas, and intense real estate activity.

The second period, following the 1950s, launched the industrialization stage, when the city received new factories. The blue-collar housing problem was aggravated, and the peripheral industrial belt was born. Meanwhile there was a slum sprawl in the city in the 1960s related to the housing deficit and the need to reduce commuting distances. In the 1970s the city was the epitome of chaos, with a million inhabitants, continuing to grow helter-skelter, with the intense production of low-income housing developments lacking basic infrastructures and services and resulting in the growth of the Greater Belo Horizonte Metropolitan Area (with a population increase of $32.9 \%$ from 1970 to 1980).

Recently, Belo Horizonte has been faced with major contrasts in the living conditions of its inhabitants, with the second worst income distribution among the 12 largest Brazilian cities (Fundação Getúlio Vargas. Pesquisa sobre Orçamentos Familiares 1999/2000. Rio de Janeiro; 2001).

\section{Adverse health events}

The following brief list of events was selected: one external cause of death, namely specific homicide mortality; one related to behavior, adolescent pregnancy; one linked to a combi- nation of individual predisposition and environmental conditions, represented by first hospital admissions for asthma in children under five years of age; and two vector-borne diseases emerging in the city, dengue and visceral leishmaniasis.

\section{- Homicides}

Homicides have been the main external cause of death accounting for the change in the Brazilian demographic profile, along with accidents and violence in general, with an increase of $103 \%$ from 1980 to 1995 6. Rates of 25.4 per 100 thousand inhabitants, among the highest in the Americas, are concentrated mainly in the metropolitan areas (World Health Organization. World Report on Violence and Health. Geneva; 2002). In Greater Metropolitan Belo Horizonte, these rates have also been increasing, with major intra-urban differences, especially in areas with worse living conditions 7 . In the central-southern area of the city, the risk of death by homicide was 16 times greater in the slum areas than in the urbanized neighborhoods from the same area 8 .

The increase in homicide rates has been associated with: social inequalities; increased destitution and poverty; an ineffective criminal justice system; increased impunity; the expansion of organized crime, which infiltrates the government apparatus through corruption and complicity by authorities; easy access to firearms; and weapons and drug trafficking 9,10,11.

\section{- Pregnancy in adolescents}

Adolescent pregnancy, moving in the opposite direction of the (declining) overall fertility rates in Brazil, has shown increasing rates, accounting for 18.2 to $22.0 \%$ of all pregnancies in the country 12,13. In Belo Horizonte, the proportion in 2001 was $16.0 \%$, varying from 6.0 to $26.0 \%$, depending on the area of the city 14 .

Adolescent pregnancy is a serious public health problem, considering its potential impact on maternal and fetal health, particularly increased perinatal and infant mortality, low birth weight, prematurity, and asphyxia 15,16, 17,18 . There is a known association between adolescent pregnancy and underprivileged socioeconomic status 19 . The negative impacts of pregnancy during adolescence appear to be more associated with social and environmental influences than direct biological factors, rein- 
forcing the relationship between this event and more adverse socioeconomic conditions 16,20.

\section{- Asthma}

Asthma is a disease involving multiple determinants. Hereditariness, intra- and extra-domiciliary pollution, and viral infections influenced by intra-domiciliary crowding are central to the determination of this condition 19,21,22 .

Asthma shows a growing prevalence, reaching the levels of a silent epidemic. In Brazil and Latin America as a whole, the prevalence ranges from 2.0 a $26.0 \%$, depending on age 23,24 .

Asthma hospitalizations show upward trends, with rates of 45 per 10 thousand under-five children 25. In Belo Horizonte it is the second most common cause of hospitalization in children under 14 years, with high rates of first hospitalizations (112.8) and re-hospitalizations (25.0) per 100 thousand children from 0 to 5 years, in 1997-2000 26 .

\section{- Dengue}

The most important arbovirus disease in humans, dengue affects 80 million individuals annually in various countries, leading to 550 thousand hospitalizations and 20 thousand deaths (Centers for Disease Control and Prevention. http://www.cdc.gov/ncidod/advbid/ dengue, accessed on 18/Jan/2004). The principal vector is the mosquito Aedes aegypti, a culicid with an extremely high capacity to adapt to urban environments.

Since 1982, the reemergence of dengue has been reported in urban areas in all regions of Brazil. The magnitude of this disease has led to high investments in vector control, epidemiological surveillance, and patient care. In the absence of an effective vaccine, etiological treatment, or effective chemoprophylaxis, combating the vector has been considered a basic strategy for its control 23 .

In Belo Horizonte, the first reports were in 1996, in the northern area of the city. Since then epidemics have taken place, first reaching welldemarcated areas followed by an unequal dispersion in the urban space. The progressive introduction of different serotypes now characterizes the co-circulation of three of the four existing types (DEN-1, DEN-2, and DEN-3) 25.

\section{- Visceral leishmaniasis}

Visceral leishmaniasis (VL) is a vector-borne zoonosis that is endemic to various countries, with 500 thousand new cases annually (World
Health Organization. The Leishmaniases and Leshmania/HIV Co-Infections. http://www.who. int/mediacentre/factsheets/fs $116 /$ en, accessed on 08/Nov/2004). In Brazil, the disease is caused by Leishmania chagasi and the infection is transmitted by Lutzomyia longipalpis and described in reservoirs like fox, opossums, and dogs 27 . Until the mid-1970s, the human disease was typically rural. In 1992, dogs were diagnosed with VL in Belo Horizonte, and in 1994 the first autochthonous human cases were confirmed. From then on, the disease expanded rapidly all over the city and to other municipalities in Greater Metropolitan Belo Horizonte 28.

With the objective of using the available information in the municipality of Belo Horizonte, this study is intended to explore the distribution of events taking place in the urban environment, characterized by explosion/implosion, identifying intra-urban differences and anticipating opportunities for interventions 29.

Two questions are in order: is there a spatial morbidity and mortality pattern in Belo Horizonte in relation to select health conditions? Is there a spatial pattern characterized by the coexistence of more than one disease or condition in populations residing in given areas of the city?

\section{Material and methods}

\section{Study area}

This ecological study was conducted in Belo Horizonte, capital of the State of Minas Gerais, with 2,238,332 inhabitants, in a territory of $330.23 \mathrm{~km}^{2}$ and with approximately 600 thousand households 30 .

The health services in the city are coordinated by a central nucleus, subdivided into nine health districts with a total of 136 basic health care units 31 .

The denominator in the study was the resident population in the planning units, created by the municipality based on census tracts. This division considers geographic aggregation, homogeneity of characteristics, and continuity of occupation, allowing socioeconomic quantification and classification of the resident population and infrastructure conditions. There were a total of 80 planning units, with a median of 25,760.5 inhabitants (varying from 2,438 to 42,268 ). Specific planning units were formed for six major clusters of slums and housing projects. 


\section{Data source}

The homicide study used the Mortality Information System (SIM), made available by the Belo Horizonte City Health Department (SMSA$\mathrm{BH}$ ), including deaths from 1998 to 2002. They included the basic causes classified as "homicides and injuries inflicted by other persons" (E960 to E969), "legal intervention" (E970 to E978), “interpersonal violence” (X85 to Y09), or "legal intervention and operations of war" (Y35 and Y36), according to the ninth and tenth versions of the International Classification of Diseases and Health-Related Problems (ICD) 32,33.

Data on adolescent pregnancies ( $<20$ years) were compiled through the Information System on Live Births for the year 2001, consolidated by the Epidemiology and Information Management Division of the SMSA-BH.

Data on first hospital admissions for asthma in children less than five years of age in 1997-2000 came from the Database on Hospital Admissions due to Respiratory Diseases, issued by the Hospital Admissions Division (SMSA-BH). Asthma diagnoses, obtained from the ICD, included respectively the ninth and tenth versions, ICD 493.0 to 493.9 and J45.0 to J46.9 33,34.

Data on dengue and visceral leishmaniasis were obtained from the National System on Reportable Diseases (SINAN), plus data recorded in the Municipal Surveillance System (SISVE) organized to supplement the city's health data, especially in relation to addresses. The study included dengue cases occurring during epidemiological weeks $01 / 2001$ to $31 / 2001$ and $34 / 2001$ to $35 / 2002$ and confirmed by laboratory or clinical/epidemiological criteria, and cases of visceral leishmaniasis reported from 1999 to 2003 , confirmed by parasitological and/or immunological tests.

For all the events, the study considered only autochthonous cases in current residents of the city of Belo Horizonte.

\section{Analysis}

Each event was georeferenced to the respective address of residence of the subject. In the absence of a precise information, the georeference was made to the closest address, using the geographic bases of blocks and stretches of streets.

As the unit of spatial analysis, the cases were aggregated in the respective planning units. We used the municipal geographic information system (GIS), produced and managed by the Municipal Information Technology and Data Company (Prodabel).
As the unit of temporal analysis, we considered the date of occurrence of each event within the defined period. The proportions and/or annual mean incidence rates were calculated per 10 thousand or 100 thousand inhabitants and divided by the number of years of observation.

In order to produce comparable rates for events with distinct frequencies, we used the proportionate mortality/morbidity ratio (PMR), which compares the indicators observed by geographic unit of analysis with the expected values obtained from the event's overall rate in the total population 34 . Next, we constructed thematic maps for the spatial distribution of PMRs for each event according to the planning units.

To study the combined spatial pattern of the events, we used the observed proportions and rates according to the planning units for each, classified in increasing order. For each unit, in relation to the set of events studied, the following score was ascribed: $0=$ none of the five events in the planning unit was among the 20 highest rates in the city; $1=$ at least one of the events in unit was among the 20 highest rates in the city; 2 = two of the five events in the unit had one of the 20 highest rates in the city; $3=$ three of the five events had one of the 20 highest rates in the city; and $4=$ four of the five events in the unit had one of the 20 highest rates in the city. The relationship between the planning unit scores and each single event was investigated through correlation analysis, using the Pearson statistic.

Spatial analysis 35 of the data used the MapInfo and Stata software.

All the studies were approved by the Institutional Review Board/Research Ethics Committee at the Federal University of Minas Gerais: homicides (no. 37/2002); characteristics of the mothers of live newborns (no. 167/2003); asthma (no. 032/2001); dengue (no. 233/2003); and visceral leishmaniasis (no. 100/2000).

\section{Results}

The events were distinguished according to occurrence, mean annual estimates, intensity, and spatial distribution. Included in the analysis were 2,801 homicide cases; 5,794 mothers under 20 years of age; 8,095 first hospital admissions for asthma; 8,074 cases of dengue; and 174 cases of visceral leishmaniasis. Losses during georeferencing varied from $0.6 \%$ for VL to $8.0 \%$ for live births.

Table 1 and Figures 1 and 2 show the results of the georeferenced data.

The 2,801 accumulated homicide cases generated a mean annual rate of 25.01 per 100 
Table 1

Events, studied periods, population at risk, and event indicators (rates or proportion).

Belo Horizonte, Minas Gerais State, Brazil, 1997/2003.

\begin{tabular}{|c|c|c|c|c|}
\hline Events studied in the city of Belo Horizonte & Period & Events* & Population & $\begin{array}{l}\text { Mean annual rate or } \\
\text { proportion of event }\end{array}$ \\
\hline Homicides & 1998-2002 & 2,801 & $2,238,332$ & $25.01 / 100,000$ \\
\hline Adolescent pregnancies $(<20 \text { years })^{\star \star}$ & 2001 & 5,253 & 33,234 & $15.8 \%$ *** \\
\hline Asthma hospitalizations $<5$ years of age & $1997-2000$ & 7,635 & $169,127 \#$ & $112.8 / 10,000$ \\
\hline Dengue cases\#\#,\#\#\# & $2001-2002$ & 7,509 & $2,238,332$ & $167.7 / 100,000$ \\
\hline Visceral leishmaniasis cases\#\# & 1999-2003 & 173 & $2,238,332$ & $1.54 / 100,000$ \\
\hline
\end{tabular}

* Considered georeferenced events. There were the following losses for total information on the event:

$7.3 \%$ for homicides; $8.0 \%$ for live births; $5.7 \%$ for asthma; $7.0 \%$ for dengue; and $0.6 \%$ for visceral leishmaniasis;

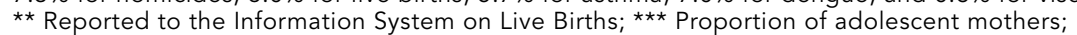

\# Children from 0 to 4 years of age. \#\# Cases reported to the National System on Reportable Diseases:

\#\#\# Refers to epidemiological weeks 1 to 31 in year 2001 and weeks 34 and 35 in year 2002.

Figure 1

Thematic maps for the proportionate mortality/morbidity ratio (PMR) for the events homicides, adolescent pregnancy (<20 years), and asthma in children under 5 years of age, Belo Horizonte, Minas Gerais State, Brazil, $1997 / 2003$.

Figure 1a

Homicides

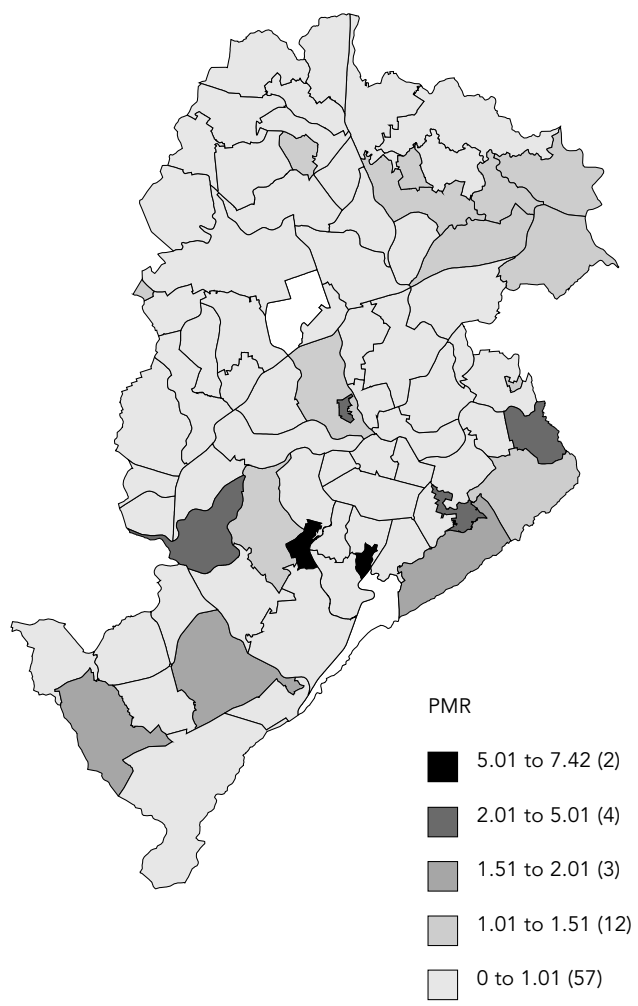

Figure $1 b$

Adolescent pregnancy

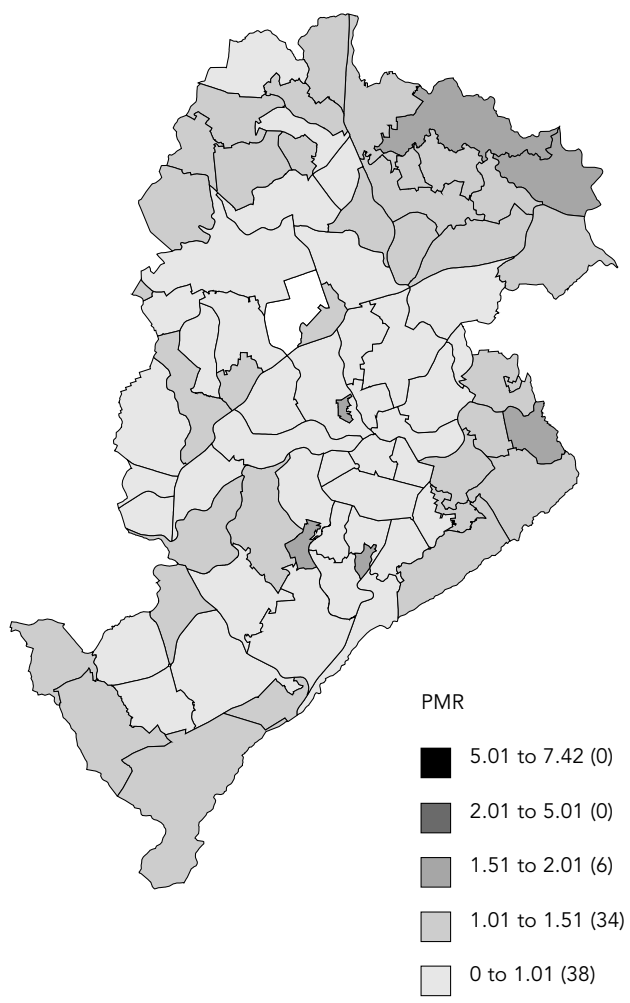

(continues) 
thousand inhabitants, varying according to the planning units, from 0 to 186 per 100 thousand inhabitants. The PMR varied from 0 to 9.27 indicating that in $18(22.5 \%)$ of the 80 planning units, the homicide rates were 1.5 to 9.3 times higher than in the city as a whole, with particular emphasis on three planning units represented by slum complexes located in the downtown area of the city.

The 5,253 adolescent mothers (with $15.8 \%$ of the live births in 2001) were distributed heterogeneously in the city, varying from 0.0 to $29.0 \%$. The PMR varied from 0.0 to 2.0 , indicating that in five planning units $(6.3 \%)$, adolescent mothers accounted for 1.5 to 2.0 times more live births than in the city as a whole. Of these, three units were situated on the northern and northeastern limits of the city and two in the central area, coinciding with two slum complexes, one of them described previously for homicides.

Of the 7,635 cases of first hospital admissions for asthma in children under five, the mean annual incidence rate was $112.8 / 10$ thousand, varying from 0 to 316 per 10 thousand children. The PMR ranged from 0 to 5.01, and six planning units $(7.5 \%)$ showed hospitalization rates twice that of the city mean. It is interesting to note that three planning units were the same slum complexes coinciding with the high homicide rates, one unit coincided with a slum complex with a high proportion of adolescent mothers, and two units coincided with an area showing intense motor vehicle traffic linking the central to the northern area of the city.

For the vector-borne diseases, there was a sharp change in the previously described profiles. An intense variation (0-74.7/10 thousand inhabitants) in the mean annual dengue rates (16.77/10 thousand) were found in the 7,509 georeferenced cases (93.0\%). Despite the major dispersion of the disease throughout the city, there was a relative grouping in 19 planning units, with a PMR 1.5 times that of the mean for the city. Particularly apparent were units located in the northernmost areas of the city, crossed by two heavily traveled highway corridors, one running north-south and the other east-west. There was also a grouping of units with lower incidence rates and PMR less than 1.0, especially in the central area and part of the east, west, and south of the city.

The mean annual visceral leishmaniasis rate was 1.54 per 100 thousand inhabitants, ranging from 0 to 28.34/ 100 thousand inhabitants per planning unit, with a distribution characterized by clustering of the disease in the northern area of the city. Seven units showed a PMR twice that of the city mean, four bordering other
Asthma

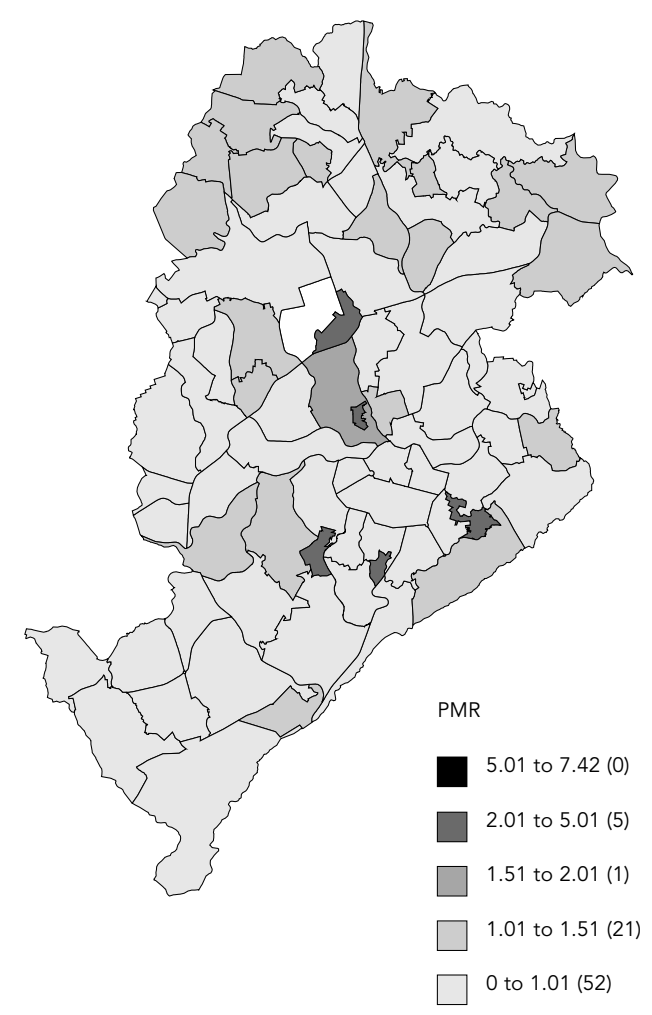

municipalities in the north, and a small located in the extreme northwest.

Comparing the planning units in terms of the two vector-borne diseases, one observes that about one-third of the areas with the highest PMRs for visceral leishmaniasis coincided with those of dengue. In addition, the planning units with the highest leishmaniasis rates appear to surround (in complementary shape) the dengue areas, in the north-northeastern portion of the city.

In the superimposed analysis of the events by scores, of the 80 planning units evaluated, $31(38.6 \%)$ were scored as $0 ; 19$ as 1 (23.7\%); 13 each as 3 or 4 (16.5\% each); and four $(5.0 \%)$ as 4 (Figure 3). Although no unit simultaneously had all five events among the 20 highest rates in the city, four units did score 4 and represented extremely disfavored areas in the city.

Observing the correlation between the units' scores and the independent occurrence of events (data not shown), one observes a good-to-excellent positive correlation between the plan- 
Thematic maps of the proportionate mortality/morbidity ratio (PMR) for cases of dengue and visceral leishmaniasis, Belo Horizonte, Minas Gerais State, Brazil, 1999/2003.

Figure 2a

Dengue

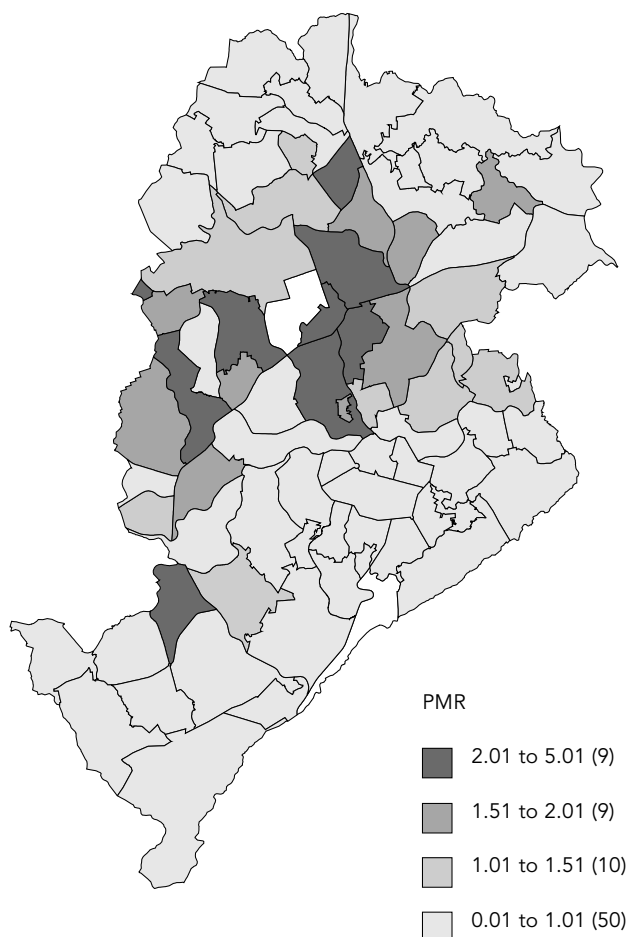

Figure $2 b$

Visceral leishmaniasis

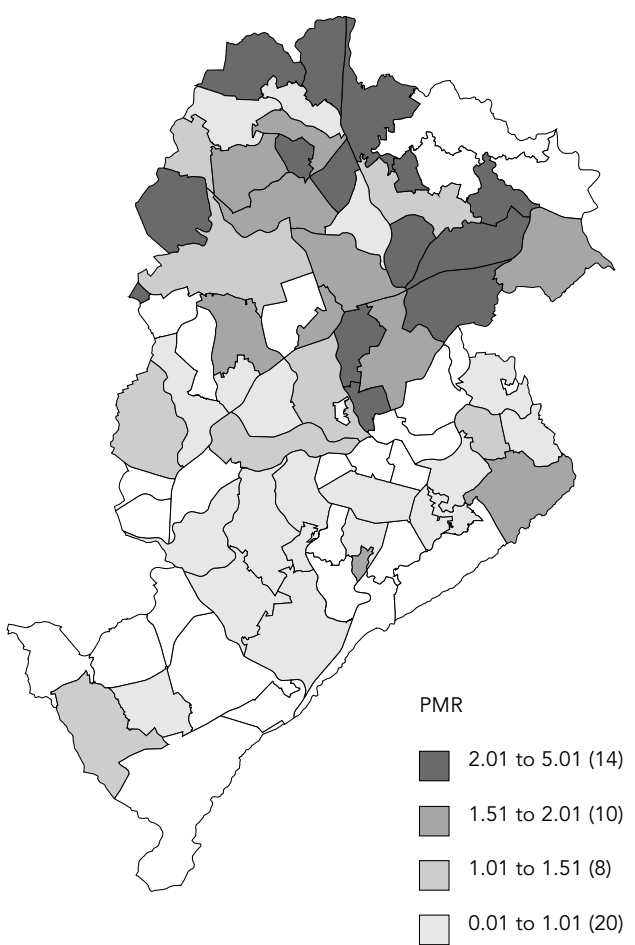

ning units with scores among the 20 highest in the city for the following events: homicides, adolescent pregnancy, and asthma, with correlation coefficients from 0.60 to 0.79 . Meanwhile, for vector-borne diseases one observes a dispersion of the comparisons with the previous events, hardly suggestive of correlation. Among the vector-borne diseases, one observes a scores correlation in $33 \%$ of the planning units.

\section{Discussion}

This study showed a spatial mortality and morbidity pattern in Belo Horizonte characterized by the overlapping of health related events for those residing in specific areas of the city.

High homicide rates in 16 planning units, a high proportion of adolescent mothers in five, and high asthma-related hospitalization rates for under-five children in six planning units overlapped in regions characterized by major social inequalities, represented by the most underprivileged population strata, particularly three of the city's eight slum complexes.

As for vector-borne diseases, one characterized by dispersion and the other by concentration of the events, the study showed clusters of high rates in underprivileged areas as opposed to low rates in higher-income areas. It is worth mentioning that the coexistence of the two diseases in the same areas of the city was less frequent, suggesting a possible role of environmental factors in the modulation of these events.

The results of this study suggest that Belo Horizonte, originally planned to function as a "healthy organism", is now characterized by a differentiated urban development and social 
profile, where health related events reflect conditions of social segregation 4.

A wide variety of studies have used different methodologies to examine the determinants and clusters of health events using spatial classifications 36,37 . Spatial analysis of epidemiological patterns has been used to evaluate the impact of structural social processes in the determination of health events, allowing the planning of both emergency and nonemergency measures 38 .

This study used a standardized comparison with proportionate mortality/morbidity ratios (PMRs) among planning units in the city of Belo Horizonte to test unequal mortality and morbidity spatial distributions for given health events in relation to the mean for the city as a whole, characterizing the intensity of events in given regions, using comparative maps 39 .

The spatial coexistence of health conditions that have already been shown to be related to social inequalities, such as homicides, a high proportion of adolescent pregnancies, and high hospitalization rates due to asthma in children under five years of age revealed a heavy burden of health related events for those living and coexisting with areas characterized by poverty, indigence, an inoperative justice system, increased impunity, and expansion of organized crime. These areas are also characterized by underprivileged social groups, represented by the poorest strata of the population, with low-income and low-schooling families in which adolescent pregnancy is a frequent event (along with its negative consequences) $14,18,20$.

Asthma in children under five, due to its multiple determinants, complements the chain of social inequality, considering not only the determinant factors for the disease itself but especially the determinants of hospitalization, associated with the socioeconomic conditions of some population groups 21,26.

In addition, it is necessary to discuss the possibility of visualizing the effects of environmental interventions, especially those that target dengue control and its possible impact on the occurrence of visceral leishmaniasis in the municipality, supporting the hypothesis of coexistence of these two vector-borne diseases in the same areas. Some studies emphasize the modification in the incidence of visceral leishmaniasis in the presence of vector control programs for malaria and Chagas disease 28,40 . It is plausible that the various modalities of Aedes aegypti vector control measures adopted since the beginning of the epidemic in the city in 1996, particularly the use of ultra-low volume residual insecticides, may have interfered in
Figure 3

Thematic map of classification scores.

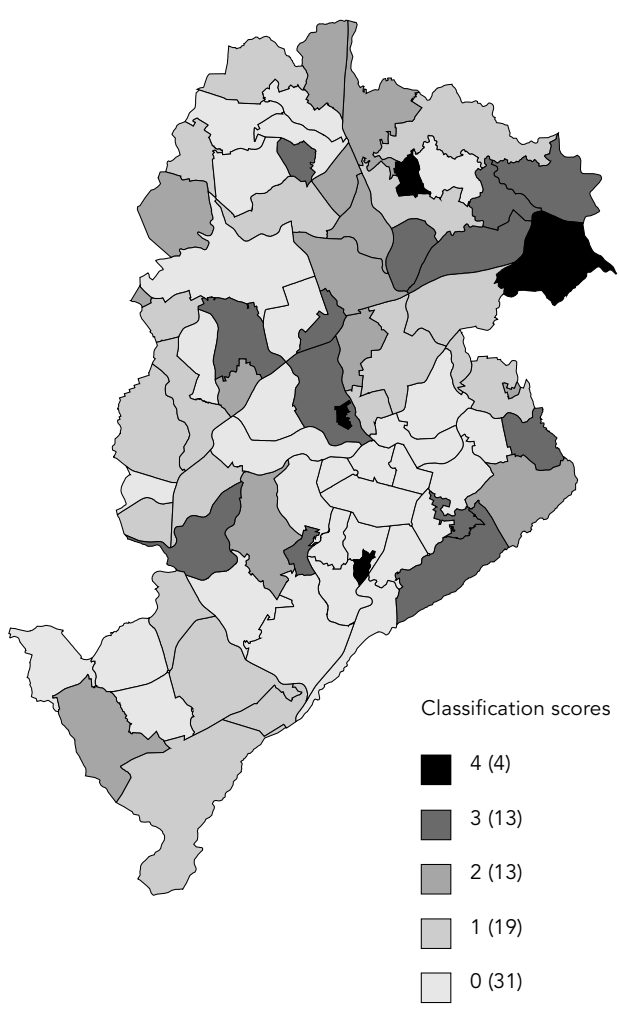

Scores: 0 = when none of the five events (asthma homicides, proportion of adolescent mothers, dengue, and visceral leishmaniasis) showed one of the 20th highest incidence rates in the city; $1=$ when at least one of the five events had one of the 20 highest incidence rates in the city; $2=$ when two of the five events had one of the 20 highest incidence rates in the city; $3=$ when three events had one of the 20 highest incidence rates in the city; and $4=$ when four of the five events had one of the 20 highest rates in the city.

the development of sand flies, so that the spatial pattern observed here may be the result of a set of dengue control measures. This hypothesis is reinforced by the possibility that chemical control of sand flies may affect culicids on a lower scale, due to more restricted systematic management of target areas under the dengue surveillance program and the use of blockade techniques in well-demarcated (and thus more restricted) areas of focal transmission 41,42.

Various limitations could be discussed before presenting a final conclusion. For example, the ecological nature of the study only considers the characteristics of the composition (rates and proportions) defined by the homo- 
geneity ascribed by the definition of the planning units. On the one hand, this can be considered an advantage, allowing comparison, but on the other it fails to consider the attributes of individual residents in these same planning units. However, the standardization of occurrence of the events, even using what is considered a synthetic statistical measure like PMR 35, allows us to locate regions in which the indicators were always higher than the means for the city as a whole.

\section{Resumo}

O objetivo desse estudo foi conhecer a distribuição de eventos em saúde em ambiente urbano. Foram georrefenciados ao endereço de residência casos de homicídios, gravidez na adolescência, internações por asma em crianças, dengue e leishmaniose visceral. A análise incluiu, para cada evento, cálculo de indicadores anuais médios, construção de mapas temáticos usando o indice comparativo de morbidade, além da criação de escores do padrão de ocorrência simultânea dos eventos por unidade espacial. Taxas elevadas de homicídio, de mães adolescentes e de internação por asma foram observadas em áreas de grandes desigualdades sociais do município. Para as doenças vetoriais, foram encontradas aglomerações de altos índices dos eventos em regiões desfavorecidas em contraponto com baixos indices em regiões favorecidas, além da relativamente pouca coexistência dos dois agravos nas mesmas regiões do município. O estudo sugeriu a coexistência espacial de agravos consagrados como resultantes das desigualdades sociais, em áreas caracterizadas pela miséria e pobreza, com grupos sociais desfavorecidos, representados pelas camadas mais pobres da população. Sugeriu também uma possível participação de fatores ambientais na modulação dos eventos de origem vetorial.

Cidades; Análise Espacial; Saúde Urbana

\section{Collaborators}

W. T. Caiaffa coordinated the project in preparing and drafting the article. M. C. M. Almeida and C. L. Oliveira managed the data processing, and together with the other authors (A. A. L. Friche, S. G. Matos, M. A. S. Dias, M. C. M. Cunha, E. Pessanha, F. A. Proietti) accompanied the discussion and collaborated in drafting the article.
Another limitation is that the identification of clusters does not lead directly to the identification of environmental determinants of a given event 40 .

Despite all the limitations presented, studies that attempt to aggregate adverse health events in urban space can provide informative spatial profiles, contributing with theoretical information to support and orient interventions, especially in populations residing in high-risk areas for various health events.

\section{References}

1. Schwartz S, Susser E, Susser M. A future for epidemiology. Ann Rev Public Health 1999; 20:15-33.

2. Barreto ML, Carmo EH, Santos CAS, Ferreira L. Emergentes, re-emergentes e permanecentes: tendências recentes das doenças infecciosas e parasitárias no Brasil. Inf Epidemiol SUS 1996; 5:7-18.

3. Harpham T, Molyneux C. Urban health in developing countries: a review. Progress in Development Studies 2001; 1: 113-37.

4. Prefeitura Municipal de Belo Horizonte. BH 100 anos: uma lição de história. 2001-2004. http://www. portal2.pbh.gov.br (accessed on 20/Nov/2004).

5. Monte-Mor RLM, Lemos CB, Costa HSM. Belo Horizonte: espaços e tempos em construção. Belo Horizonte: Centro de Desenvolvimento e Planejamento Regional, Universidade Federal de Minas Gerais; 1994.

6. Yunes J, Zubarew T. Mortalidad por causas violentas en adolescentes y jóvenes: un desafío para la región de las Américas. Rev Bras Epidemiol 1999; 2:102-71.

7. Lima ML, Ximenes R. Violência e morte: diferenciais da mortalidade por causas externas no espaço urbano do Recife, 1991. Cad Saúde Pública 1998; 14:829-40.

8. Ishitani LH, Rezende EM, Mendonça ML, Lopes HMRO, Souza DAP, Miranda PSC. Mortalidade por homicídios em bairros e favelas da região centrosul de Belo Horizonte. Rev Méd Minas Gerais 2001; 11:7-10.

9. Minayo MCS. Violência social sob a perspectiva da saúde pública. Cad Saúde Pública 1994; 10:7-18.

10. Barata RB, Ribeiro MCSA, Moraes JC. Tendência temporal da mortalidade por homicídios na cidade de São Paulo, Brasil, 1979-1994. Cad Saúde Pública 1999; 15:711-8.

11. Proietti FA, Matos SG. Homicide mortality in Belo Horizonte: inequality during lifetime and in death, 1998-2000. J Urban Health 2003; 80 Suppl 2: ii125-6. 
12. Instituto Brasileiro de Geografia e Estatística. Censo demográfico, 2001. Rio de Janeiro: Instituto Brasileiro de Geografia e Estatística; 2002.

13. Bacon JL. Adolescent sexuality and pregnancy. Curr Opin Obstet Gynecol 2000; 12:345-7.

14. Friche AAL, Caiaffa WT, César CC, Goulart LMF. Qualidade dos dados do Sistema de Informação sobre Nascidos Vivos - SINASC - em Belo Horizonte, 1999. In: VI Congresso Brasileiro de Epidemiologia, 2004. Recife: Associação Brasileira de Pós-Graduação em Saúde Coletiva; 2004.

15. Rodrigues CS, Magalhaes Jr. HM, Evangelista PA, Ladeira RM, Laudares S. Perfil dos nascidos vivos no Município de Belo Horizonte, 1992-1994. Cad Saúde Pública 1997; 13:53-7.

16. Menezes AMB, Barros FC, Victora CG, Tomasi E, Halpern R, Oliveira ALB. Fatores de risco para mortalidade perinatal em Pelotas, RS, 1993. Rev Saúde Pública 1998; 32:209-16.

17. Lansky S, França E, Leal MC. Mortes perinatais evitáveis em Belo Horizonte, Minas Gerais, Brasil, 1999. Cad Saúde Pública 2002; 18:1389-400.

18. Gama SGN, Szwarcwald CL, Leal MC. Experiência de gravidez na adolescência, fatores associados e resultados perinatais entre puérperas de baixa renda. Cad Saúde Pública 2002; 18:153-61.

19. De Britto MC, Bezerra PG, Ferreira OS, Maranhão IC, Trigueiro GA. Asthma prevalence in schoolchildren in a city in northeast Brazil. Ann Trop Paediatr 2000; 20:95-100.

20. Bale JR, Stoll BJ, Lucas AO. Improving Birth Outcomes. Meeting the challenge in the developing world. Washington DC: Committee on Improving Birth Outcomes, U. S. Institute of Medicine, National Academy of Sciences; 2003.

21. Chatkin M, Menezes AMB, Albernaz E, Victora CG, Barros FC. Fatores de risco para consultas em pronto-socorro por crianças asmáticas no Sul do Brasil. Rev Saúde Pública 2000; 34:491-8.

22. Mallot J, Cortez E, Amarales L, Sanches I, Calvo M, Soto S, et al. Prevalencia del asma en escolares chilenos. Estudio descriptivo de 24.470 niños. ISAAC-Chile. Rev Med Chile 2000; 128:279-85.

23. Tauil PL. Urbanização e ecologia do dengue. Cad Saúde Pública 2001; 17:99-102.

24. Centers for Diseases Control and Prevention. Promote respiratory health through better prevention, detection, treatment and education efforts. http://www.cdc.gov (acessado em 20/Jun/2004).

25. Almeida MCM, Caiaffa WT, Assunção RM, Proietti FA. Dinâmica intra-urbana das epidemias de Dengue em Belo Horizonte, MG, 1996-2002. In: VI Congresso Brasileiro de Epidemiologia. Recife: Associação Brasileira de Pós-graduação em Saúde Coletiva; 2004.

26. Dias MAS, Caiaffa WT, Machado-Coelho GLLM. Poverty is associated with asthma hospitalization and re-hospitalization rates, 1997-2000: an ecological analysis in Belo Horizonte City, Brazil. J Urban Health 2003; 80:ii108-9.
27. Sherlock I. Ecological interactions of visceral leishmaniasis in the State of Bahia, Brazil. Mem Inst Oswaldo Cruz 1996; 91:671-83.

28. Oliveira CL, Assunção RM, Proietti FA, Reis IA. Spatial distribution of human and canine visceral leishmaniasis in Belo Horizonte, 1994-1997. Cad Saúde Pública 2001; 17:1231-9.

29. Lefèbvre H. A revolução urbana. Belo Horizonte: Editora UFMG; 1999.

30. Secretaria Municipal de Planejamento. Anuário estatístico de Belo Horizonte 2000. Belo Horizonte: Secretaria Municipal de Planejamento; 2001.

31. Instituto Brasileiro de Geografia e Estatística. Censo demográfico 2000: resultado do universo. Rio de Janeiro: Instituto Brasileiro de Geografia e Estatística; 2002.

32. Organização Mundial da Saúde. Manual da Classificação Estatística Internacional de Doenças, Lesões e Causas de Óbitos - Nona conferência de revisão. São Paulo: Centro Brasileiro de Classificação de Doenças em Português; 1985.

33. Organização Mundial da Saúde. 1995. Classificação Estatística Internacional de Doenças e Problemas Relacionados à Saúde, 10a revisão. v. 1. São Paulo: Centro Colaborador da OMS para a Classificação de Doenças em Português; 1995.

34. Mausner JS, Baun K. Epidemiology: an introductory text. Philadelphia:WB Saunders; 1985.

35. Bailey TC, Gatrell AC. Interactive spatial data analysis. Essex: Longman Scientific \& Technical; 1995.

36. Wennberg JE. Understanding geographic variations in health care delivery. N Engl J Med 1999; 340:52-3.

37. James WL, Cossman RE, Cossman JS, Campbell C, Blanchard T. A brief visual primer for the mapping of mortality trend data. Int J Health Geogr 2004; $3: 7$.

38. Barcellos C, Bastos FI. Geoprocessamento, ambiente e saúde: uma união possível? Cad Saúde Pública 1996; 12:389-97.

39. Glass GE. Update: spatial aspects of epidemiology: the interface with medical geography. Epidemiol Rev 2000; 22:136-9.

40. Costa CH, Pereira HF, Araújo MV. Epidemia de leishmaniose visceral no Estado do Piauí, Brasil, 1980-1986. Rev Saúde Pública 1990; 24:361-72.

41. Ministério da Saúde. Instruções para pessoal de combate ao vetor: manual de normas técnicas. Brasília: Ministério da Saúde; 1997.

42. Gurgel IGD. O controle das endemias: o descontrole ambiental. In: VI Congresso Brasileiro de Saúde Coletiva, Salvador: Associação Brasileira de Pós-graduação em Saúde Coletiva; 2000.

Submitted on $22 / \mathrm{Dec} / 2004$

Final version resubmitted on $10 / \mathrm{Feb} / 2005$

Approved on 14/Feb/2005 